\title{
NATURE
}

\section{This Way to Nowhere}

THE safest thing to say about the year ahead is that it will be much like the immediate past. This, after all, is a good rule in weather forecasting. Even in outlandish places like the British Isles, there are two days out of three on which it is fair to say that tomorrow will be like today (which implies not too great an insistence on detail in the forecast). And in some sense, of course, the year ahead will be very much like the year past. The same sort of things will be happening. Neither $\mathrm{Mr}$ Robert Kennedy nor $\mathrm{Mr}$ Luther King can be shot a second time, of course, but there are plenty of other opportunities for tragedy. If the Moon is old hat by the beginning of 1970, there will still be room for speculation about the benefits of going somewhere else-Mars, Venus or just in circles. Then there is no doubt that students will continue to be taught, in spite of all the appearances to the contrary on several recent occasions; patient research will continue in the universities and institutes, while the diligent public servants who are at once the envy and the end-points of the rest of us will continue to sit on public committees, seeking to improve the effectiveness of what other people do or, occasionally, to nullify it. In circumstances like these, the turn of the year is necessarily a time when people are aware that the future is constructed from the past and that the immediate interest is to pick out the signs of change or at least of challenge.

By all appearances, the year ahead has the smell of unpleasantness, certainly for those whose interests lie in professional science and the related professions. The year past has seen the intellectual community exposed to a host of threats, many of them unexpected. Worse still, it has seen the intellectual community react to obvious assaults on its security, not by robust defence or even by guile, but by a pretence that if only people can carry on as if there is nothing to worry about, their troubles will spontaneously pack up and go away. That is a dangerous illusion.

The universities provide a splendid illustration of how the people most of all concerned with them are almost indifferent to the way in which problems are accumulating. In Britain, for example, the only public issue which has really raised the interest of the academic world in the year just past is the report in which the Prices and Incomes Board awarded university teachers a miserly pay increase and then went on to say that there should be some kind of bonus for the good teachers which might, in part, be determined by the opinions of the students. Academic wrath seems to have induced no less a person than the Prime Minister to intervene and say that he would never countenance the involvement of students in this way. Outsiders, however, will be puzzled to know why academics have not been biting their nails with anxiety about the real problems which arise from the nearly complete dependence of the university system on funds from the central government. The people who have been protesting about the Prices and Incomes Board should be just as much concerned about the function of the University Grants Committee and the question of how the universities are to present a unified case to the outside world. Academics should also be desperately concerned about the signs of weakness which have now emerged within the university system. It is, for example, now plain for all to see that a population as small as that of Britain cannot successfully support forty-five universities unless there is a great deal of rationalization and even frank inequality among them. What is to be done about that? And what is to be the considered response of academics to the challenge which the students have presented in the past two years? Universities have yet to find a course that lies somewhere between capitulation and the pretence that there is no need of change. What is it to be ?

There is a similar range of untackled problems in the management of university research. In Britain and in the United States, there has recently been a noticeable reluctance of politicians to spend their electors' taxes in such a way as to increase the funds available for university research at such a speed that a growing number of academics ean carry out research on the scale established in the late fifties. It is important to reeognize that this is not mere parsimony but the consequence of a real political dilemma-how to balance the cost and benefits of university research against the costs and benefits of other public expenditures. In the United States, of course, there is a great need of better machinery-the National Science Foundation should be strengthened-but this will not by itself provide all the money which the growing army of university teachers could profitably use to enliven their teaching. So what are the universities going to do ? Will they return to shoestring research, or will they, as they should, set out to create much closer links between publicly supported laboratories and the universities which are frequently alongside them ? The way that things are going, there is a real danger that the quality and the intensiveness of university research will be undermined by the unavoidable restrictions on the supply of funds. One obvious difficulty is that this problem cannot simply be made to vanish by complaining at the Government. It would be splendid if the people most of all concerned chose to spend a part of their energy, in the year ahead, facing up to this urgent need. If they do not, they will have only themselves to blame. 